\title{
Event-Stratification in Nummulite Accumulations and in Shell Beds from the Eocene of Egypt
}

T. AIGNER

Abstract: The concept of event-stratification may successfully be applied to two types of bioclastic deposits in the Eocene of Egypt :

1. Middle Eocene Gizehensis-Bed: physical processes ("winnowing events") are significantly involved in structuring and in-situ accumulating nummulitic sediment bodies.

2. Upper Eocene shell beds: reveal a complex series of erosion and colonisation events over a certain time interval, each "physical process" being followed by a "biological response".

1. Introduction

The Eocene of Egypt comprises shallow-marine and marginal sediments that were deposited in narrow and elongated tectonic basins forming embayments of the Tethys. Early and Middle Eocene were times of carbonate sedimentation, but due to regression, sediments became essentially terrigenous from the Late Eocene onwards. Compilations on stratigraphy and sedimentation patterns are provided by SAID (1962) and SALEM (1976) .

The object of this paper is to apply the concept of "event-stratif ication" to two rather different kinds of shell deposits:

1. Accumulations of nummulites as a very special case of bioclastics.

2. Several prominent and laterally persistent shell beds, that are being used for refined stratigraphic correlation (STROUGO 1977 ).

2. Nummulite Accumulations Structured by Physical Events

2.1. Previous Work

The sedimentological aspects of such bioclastic deposits that contain nummulites in rock-forming quantities have so far received little attention. Generally, nummulites are believed to have formed autochthonous "banks" or "bioherms" or they are even considered as reef-builders (ARNI 1965; ARNI \& LANTERNO 1972, 1976; DECROUEZ \& LANTERNO 1979) . 


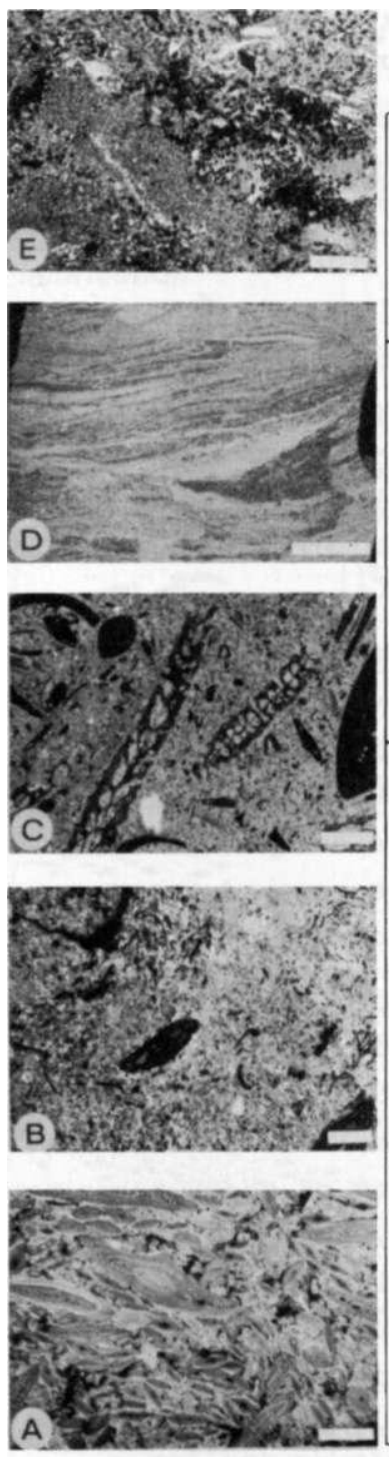

\section{MOKATTAM}



Shell beds

LITTORAL

«Taf la»(gypsiferous)

RESTRICTED

LAGOON

PROT EC T ED

Bryozoa - Limestone PL ATFORM

Upper BACK-BANK

Building Stone OPEN SHELF

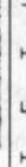

:

$z$

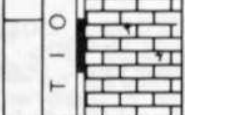

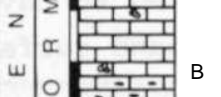

Gizehensis - Bed

L ower

Building Stone
NUMMULITE - BANK

FOREBANK

Fig. 1. Stratigraphic summary log of Middle and Upper Eocene in the Mokattam-Hills (E of Cairo) and tentative environmental Interpretation. The Gizehensis-Bed (Mokattam-Formation) and several shell beds (Maadi-Formation) are discussed here

However, nummulites have also been recognised to occur wave-affected (ARNI \& LANTERNO 1972), reworked in shoals and fore-reef channels (SANTISTEBAN \& TABERNER 1980), in cross-bedded littoral series 
(RONIEWICZ 1969) and in turbidites (ENGEL 1970). FOURNIE (1975) compared certain nummulite accumulations with ooids shoals and related them to an analogous hydrodynamic regime.

\subsection{Stratification Types in the Gizehensis-Bed}

The Middle Eocene Nummulites gizehensis-Beä was studied in classical exposures at the Giza Pyramids Plateau (W of Cairo) and in the Mokattam Hills (E of Cairo, Fig. 1), where limestones appear generally massive or relatively thick-bedded $(0.5-1.5 \mathrm{~m})$ with 1 $50 \mathrm{~cm}$ marly intercalations. They consist largely of nummulite-biomicrites showing wackestone/packstone depositional textures (Fig. 4), but grainstones may also occur. The following features bear on their origin (Fig. 2) :

(1) Firmground Horizons. The bases of many nummulite beds are Sharp and erosional, showing large-scale scours and small-scale pockets (pot holes), as well as burrows, both typical for firmground conditions (Gloasifungites -facies, SEILACHER 1967). Major hydrodynamic events (hurricanes?) eroding the seafloor down to already compacted levels are inferred to have exposed these laterally fairly persistant firmground surfaces.

(2) Erosive Pockets and Pot Holes. Pot holes and pockets occur in association with firmgrounds as well as within nummulite beds (Fig. 3). They commonly show a densely packed grainstone fill with edgewise imbrication and fan position of nummulites and are most common in the shallowest parts towards the top of the GizehensisBed (probably a "Nummulite Bank"), where they indicate the composite and amalgamated nature of the beds (Fig. 3). These pockets resemble the pot holes described by DORR \& KAUFFMAN (1963) and AIGNER \& FUTTERER (1978), which are referred to strong vortex currents during storm events.

(3) Scour-and-Fill structures (Fig. 2). Within massive, apparently unstratified beds, scour-and-fill structures occur in various Orders of magnitude. They are much broader (up to several dm) and filled with nummulite-packstones. Their lower boundary is commonly shallow channel-like or sinusoidal but normally nonerosive.

(4) Planar Lags. (Fig. 2). Thin planar layers of nummulite packstone are also common and may almost exclusively consist of the larger B-forms of Nummulites gizehensis, which are often Imbri- 
Physical Events in Nummulite-Banks

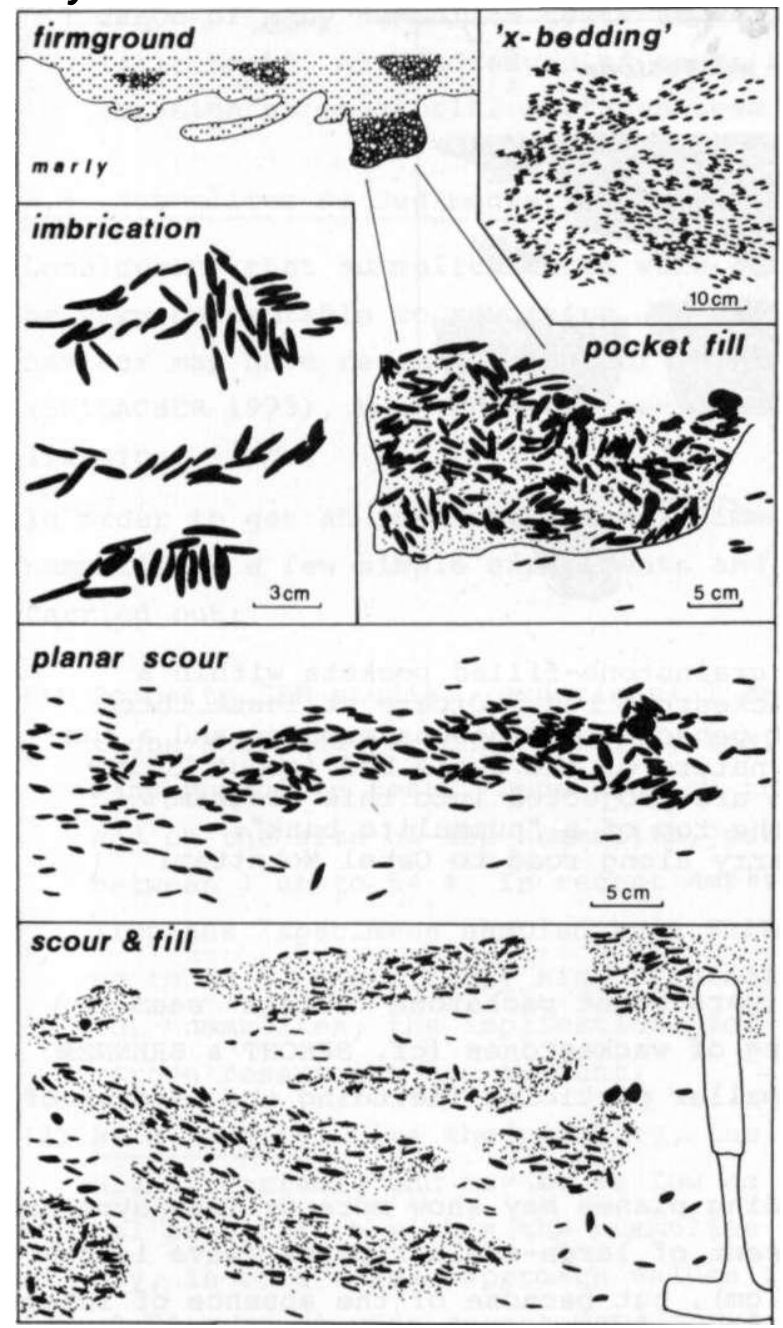

Fig. 2. Biofabrics in Nummulite-accumulations ("Gizehensis-Bed") reflect physical processes as structuring and stratifying agents. Note:

- extensively bürrowed firmgrounds with erosive relief,

- erosive pockets filled with biosparite,

- imbrication,

- stratification reminiscent of cross-bedding,

- Nummulite-concentrations on planar scours,

- small-scale scour and fill structures 


\section{Composite Bed}

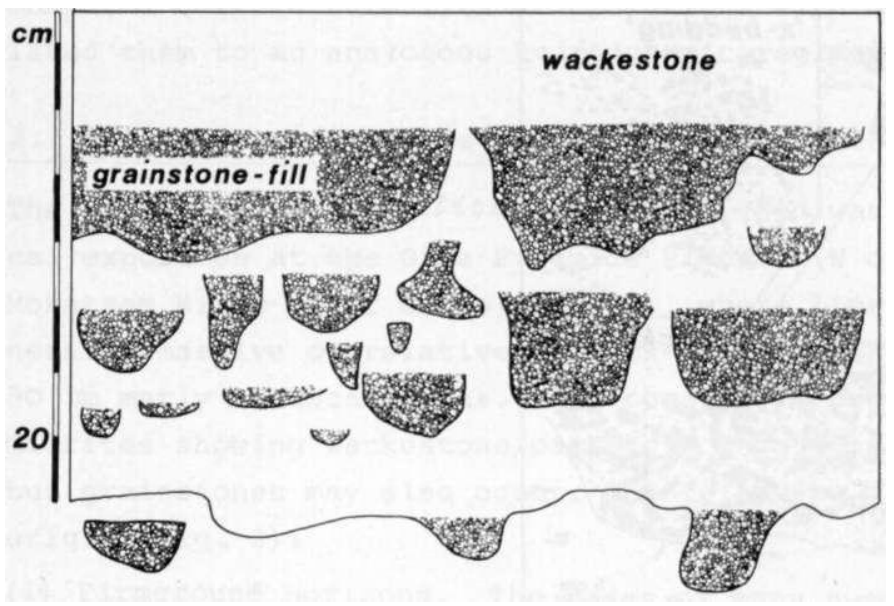

Fig. 3. Levels with erosive grainstone-filled pockets within a massive Nummulite-wackestone bed indicate at least three discrete episodes of penecontemporaneous erosion and a composite, amalgamated nature of the whole bed (about 20 metres lateral outcrop are projected into this diagram). This is a bed from the top of a "nummulite bank". (Gizehensis-Bed, quarry along road to Gebel Mokattam)

cated. These laterally persistent packstone-"sheets" seem to have formed by winnowing of wackestones (cf. SPECHT \& BRENNER 1979) and removal of smaller particles including the A-forms of the nummulites.

(5) Erosive Ripples. Bedding planes may show more or less symmetrical undulations reminiscent of large-scale ripples (wave length 60-100 cm, height 10-25 cm), but because of the absence of internal structures typical for ripples and due to the highly variable shape, these undulations more likely represent "erosive ripples" (cf. REINECK \& SINGH 1975, Fig. 8; GOLDRING 1971, Fig. 15) or "scour ripples" (BAILEY 1966, Fig. 1) rather than normal ripples.

(6) Imbrication. Both "contact" and "isolate" imbrication (LAMING 1966) is common, especially in local concentrations of the larger and flatter B-forms of $n$. cjizehensis (Fig. 2), while edgewise imbrication was only occasionally observed. Current action thus seems to have been more important than pure wave action.

(7) Sorting and Fragmentation. Sorting is normally poor, expressed by the association of small A-forms and larger B-forms of $s$. 
gizehensia. Thin-sections reveal the worn and fragmented appearance of many nummulite tests as well as the abundance of "nummulitic hash". Abraded edges of tests are most conspicuous, while abrasion on equatorial surfaces seem to be less common.

\section{4. iMummulites as Sedimentary Particles}

Considering that nummulite tests were extremely porous, they should be very susceptible to reworking, so that their sedimentological behaviour may have resembled that of crinoid remains originally

(SEILACHER 1973), but may have been drastically altered by prefossilization.

In order to get an idea about the sedimentological behaviour of nummulites, a few simple experiments and calculations have been carried out :

(1) Porosity.SKM-studies, experimental and mathematical determinations show that a considerable porosity is still preserved in many nummulite tests. Depending on the surrounding rock type and on the size of the nummulite, porosity was found to ränge between 1 up to 54 8. In recent Amphisorus tests from the Philippines (specimens sampled by A.SEILACHER), porosity reached up to $72 \%$. A similarly high original porosity can be inferred for nummulites; the implications for their potential as hydrocarbon reservoirs are evident.

(2) Bulk Density. Like the porosity, the bulk density values are $-3$

highly variable and may be as low as $1.28 \mathrm{~g} \mathrm{~cm}$. Due to internal cementation within the nummulite test, however, bulk density may, in some cases, approach values typical for pure calcite $\left(2.71 \mathrm{~g} \mathrm{~cm}^{-}\right)$. For recent Amphisorus, only $0.305 \mathrm{~g} \mathrm{~cm}^{-3}$ has been found.

(3) Settling Velocity. Determination of the settling velocity allows to deduce the diameter of hydraulically equivalent quartz grains (e.g. FUTTERER 1977, Fig. 10). In this way, nummulites with a diameter of $7-24 \mathrm{~mm}$ were found to be equivalent to $1.0-1.85 \mathrm{~mm}$ sand grains ("very coarse sand").

(4) Critical Transport Velocity. Firstly, hydraulic equivalents derived from settling experiments were used in the HJULSTRÖM-diagram: here, values for the critical transport velocity are most$-1$

ly around $30-40 \mathrm{~cm} \mathrm{~s}$. Secondly, the critical transport ve- 

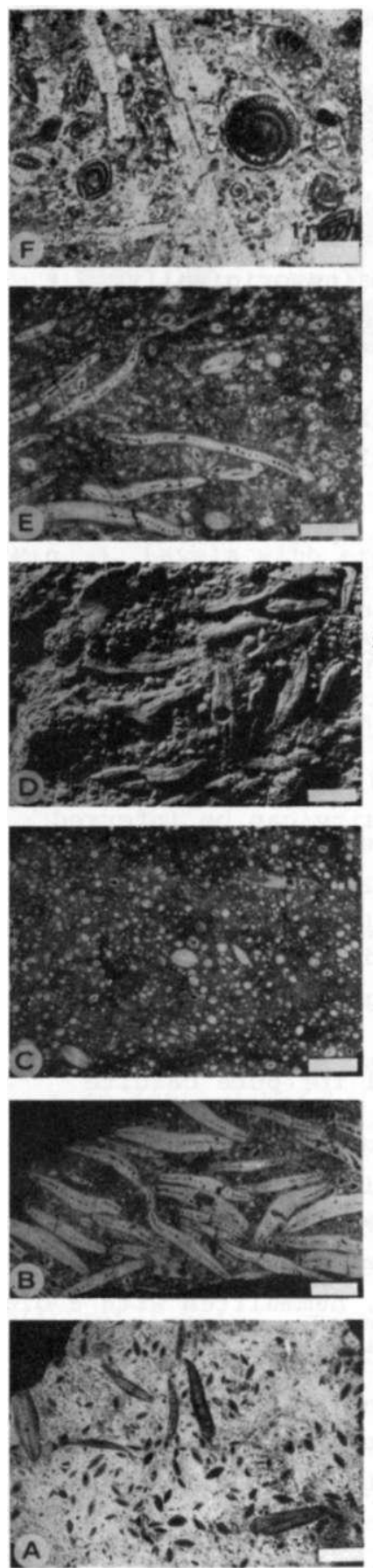

\section{GIZEHENSIS - BED}

LITHOLOGY

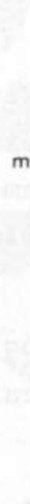

\section{.}

20

Mudstone

Wackestone

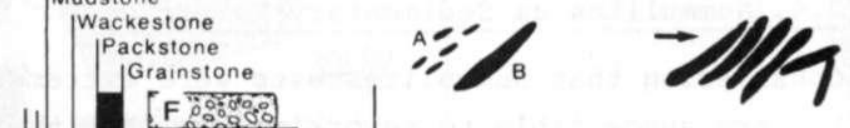

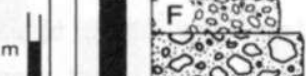

0.0010

:0\%:0

45050

0:0.0․

10000 .

$0 \% 005$

1.508

o.s. 300

arcorias?

$10.0 \% 00 \%$

$\mathrm{E}$,

E. 0.98

0.009 .09

\%

D.

80.0045

Cros:5

C

mongen.s.

8.8000

mo.

$\mathrm{B}: 0.009$

5.000 .05

8.00

588

30.90

30.598.

000 5

व्वर्ड:

TStrifo:

1000800

$100000: 0 \%$

10
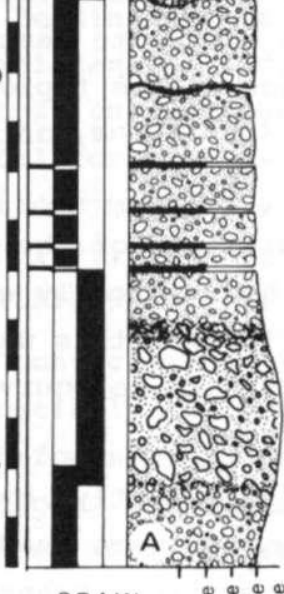

GRAIN
SIZE
A/B - RATIO

IMBRICATION
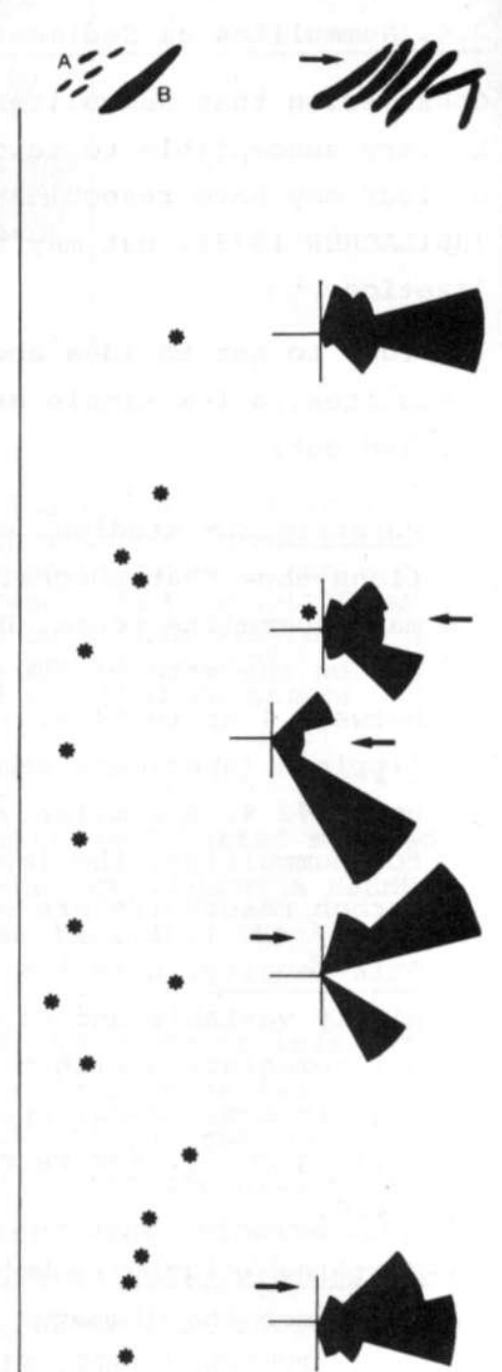

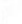
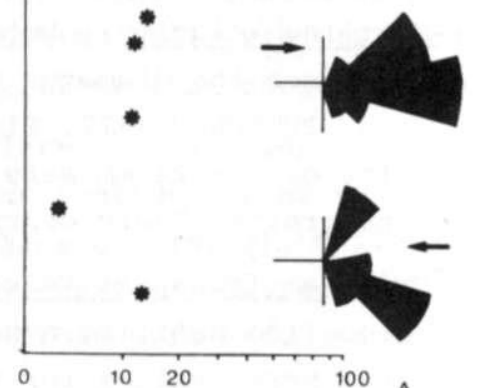

log-scale

100

$\stackrel{A}{B}$ 
locity was directly determined by flume experiments carried out by Dr. E. FUTTERER (Kiel). Here, velocities ränge between 18 $77 \mathrm{~cm} \mathrm{~s}$, which is in the same order of magnitude as the values derived from settling experiments. Dr. FUTTERER also observed, that nummulites are transported by sliding, saltation and rolling.

\subsection{Conclusions}

(1) Stratification types and biofabrics in nummulite accumulation show that physical sedimentary events were responsible for their structure. The smaller A-forms of N.gizehensia largely dominate the assemblages (Fig. 4), as BLONDEAU (1972) has postulated for their original communities. Therefore nummulites seem to have mainly accumulated in situ through winnowing events and thus have formed extensive sediment bodies (Fig. 5 ).

There is no evidence for reef-like buildup in the "Nummulite Banks" of the "Gizehensis-Bed. Due to the mechanisms involved, this type of buildup may be called "nummulite teils".

(2) Simple experiments indicate that nummulites must have been very light and susceptible to reworking at current velocities as low as 20 $-1$

- $80 \mathrm{~cm} \mathrm{~s}$. According to LOGAN et al. (1969, Fig. 3), storminduced wave-current velocities of this order of magnitude occur in waters as much as $100 \mathrm{~m}$ deep.

(3) Physical processes involved in the formation of "Nummulite Banks" may be comparable to the role of physical storm-related sedimentation in molding the character of present-day carbonate mud banks around Florida (WANLESS 1979).

Fig. 4. Detailed log showing variations of microfacies, depositional fabrics, grain size and nummulite A/B-ratio within the "Nummulites gizehensis-Bed" (northern escarpment of Giza Pyramids Plateau, along Fayum road). A-forms dominate throughout most of the sequence, but layers with relative enrichment of B-forms often correspond to packstone textures, indicating winnowing and removal of the fine particles including the A-forms. Note also abundance of imbricated fabrics (each measurements based on about 100 nummulites) 


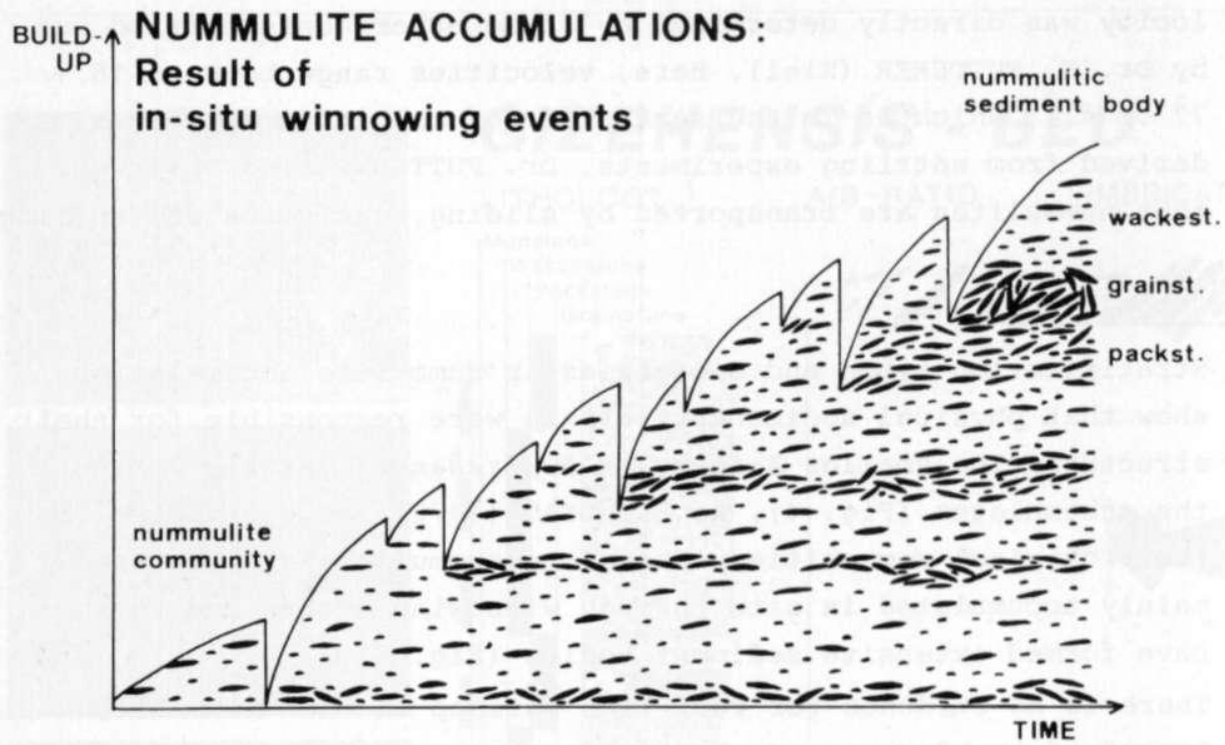

Fig. The time-buildup diagram suggests that episodic winnowing (probably storm-generated) is responsible for structure, depositional fabrics and growth of nummulite accumulations. Repeated winnowing events of varying intensity have washed away substantial amounts of lime-mud that probably represented the original substrate of nummulites (according to BLONDEAU 1972). Thus, the resulting bioclastic accumulation is slowly growing upwards like an archaeological "tellstructure" ("nummulite teil") and consists to a large extent of event-generated in-situ lag deposits, but does not represent the actual habitat conditions of the nummulites. Due to gradual shallowing, winnowed fabrics become more abundant towards the top of nummulitic sediment bodies

3. Shell Beds: Interplay Between Physical Processes and Biological

Responses

3.1. General Problems

Shell beds have been widely used for Community reconstructions (e.g. MCKERROW 1978). It has also been debated whether detailed and even quantitative reconstructions concerning mortality rates, diversity, trophic structure etc. can be derived from such accumulations of biologic hard particles. After all, they may have suffered considerable taphonomic distortion. Apart from postmortal transport, faunal changes due to minor environmental fluctuations may have obliterated the original faunal spectrum of a "Community" (cf. WILSON 1967, FÜRSICH 1978, BOUCOT 1975). 
In general, Shell beds should not be viewed indiscriminately as paleoecological portraits of paleocommunities, but should rather be analysed in their taphonomic details in order to appreciate their fül sedimentary history.

\subsection{Taphonomy and Stratification in Upper Eocene Shell Beds}

Upper Eocene shell beds, usually 0.5 tp $1.5 \mathrm{~m}$ thick, have been studied in the Mokattam Hills (cf. Fig. 1), the Giza Pyramids area, and in Quasi"-el-Sagha (Fayum Oasis). Generalised they show the following attributes (Fig. 6):

(1) Shell beds develop on scoured surfaces which are commonly burrowed by Spongeliomorpha, indicating firm substrate conditions ("firmgrounds").

(2) In most cases, these firmground horizons were colonised by Carolia as a pioneer. Similar pioneer colonisations by this epibyssate bivalve usually take place repeatedly on internal erosion surfaces within shell beds.

(3) Shell bed development is characterised by (often repeated) changes in faunal composition and sediment fabrics. Thus, Carolia colonies become frequently replaced by ostreids or by Plicatula, the former being in many cases cemented onto Carolia Shells. The oysters in turn may later be encrusted by corals, eventually leading to small-scale coral banks.

(4) Subsequent erosion may have led to partial or complete reworking of original epibenthic assemblages and to the production of shell debris. This shelly substrate in turn became inhabited by specific organisms (e.g. Ophiomorpha with pellet-ligned walls for stabilisation).

(5) Intercalations of endobenthic organisms (Spatangids, Turritella ) indicate phases of intermittent mud-sedimentation and softground conditions. Since the fine sediment itself has later became reworked and winnowed away, these shell lags represent the only "memory" (SEILACHER, this volume) of softground intervals within mostly epifaunal shell beds.

\subsection{Conclusions}

(1) Shell bed initiation in the Upper Eocene requires strong erosion (major storm event?) to create a firmground substrate, which could be used by Carolia as a post-event pioneer colonizer. 


\section{SHELL BEDS: $\begin{aligned} & \text { events, } \\ & \text { successions, }\end{aligned}$ pseudo-successions}

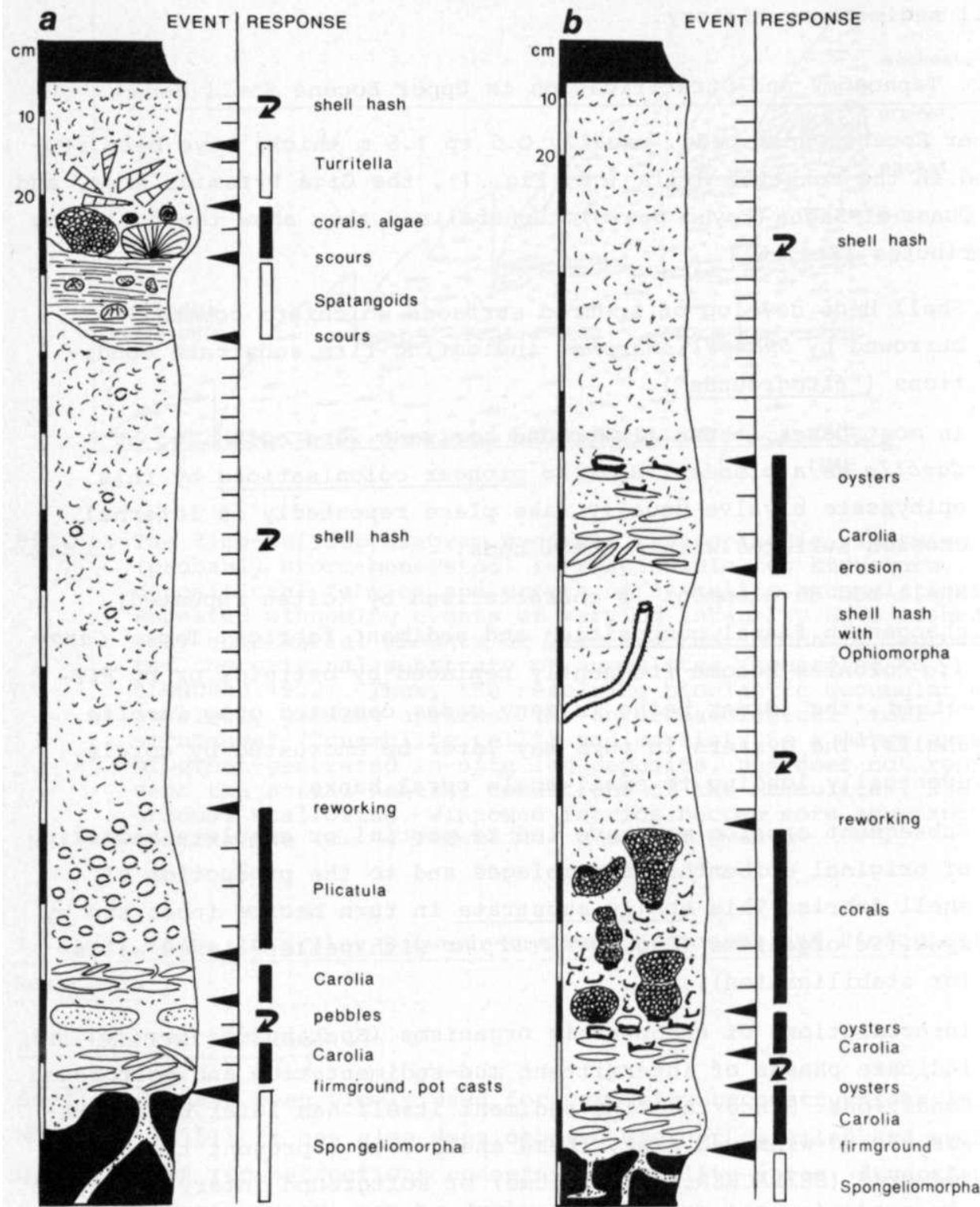

Fig. 6. Shell beds revealing a complex series of erosional/depositional events, followed by specific biological responses. Some appear to be true ecological successions, other are merely "pseudo-successions". (Black bar = epifaunal response, clear bar = endofaunal response, $a=$ "Plicatula-Bed", $b=$ "Ostrea-Bed", Mokattam-Casino section, Maadi-Formation) 
(2) Shell bed development: shell beds accumulated on such firmgrounds are essentially autochthonous, but they record a series of sedimentary events (erosion/deposition), each of which may be followed by a specific biological response (epi/endobenthic colonisation of soft, shelly or firm substrate, see Fig. 7). Although some of the resulting sequences resemble "community successions", faunal changes within shell beds seem to be primarily controlled by environmental fluctuations ("community replacement", BOUCOT 1975, HOFFMAN \& NARKIEWICZ 1977), rather than by biologically induced changes. Thus they represent only "pseudo-successions".

(3) Biostratinomy: The mechanism responsible for shell bed development can be described as a quantum-like accumulation of a larger number of "process-response Couplets" (physical event biological response) over a certain time interval. Firmground/ shell bed complexes have acted as "reference horizons", recording the interplay between ecological and sedimentary events during longer time periods.

(4) Stratigraphy: Due to their large geographic distribution and their isochronous character major shell beds are useful for high-resolution stratigraphy on a regional scale.
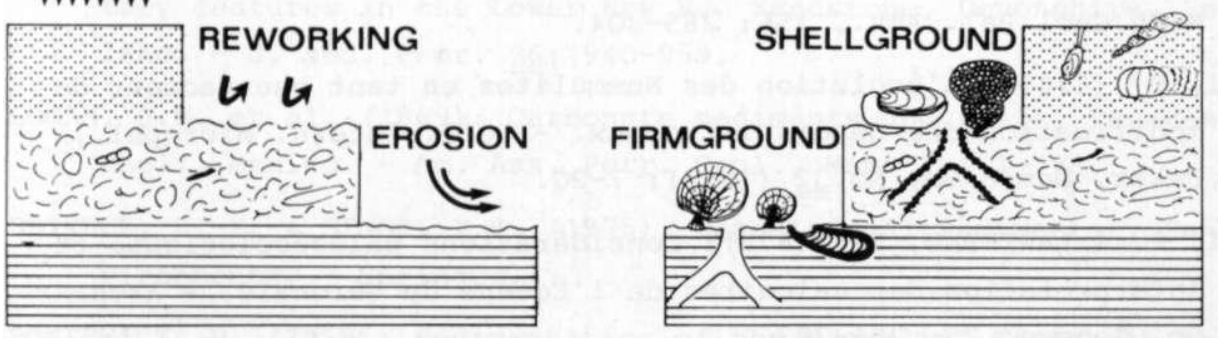

\section{PHYSICAL PROCESS

Fig. 7. Different sedimentary events or "physical processes" (sedimentation/reworking/erosion) alter substrate conditions on the sea floor and are followed by specific "biological responses" on the newly created soft-, Shell- or firmgrounds. Repetition and accumulation of such "process-response couplets" represent the baslc mechanism responsible for the development of the complex shell beds described here 
(5) Evolution: Since many similar shell beds with analogous but morphologically different faunas occur at different levels, they might provide the opportunity to study the tempo and mode of evolutionary changes in the "post-event fauna" as compared to the "background fauna" (SEILACHER 1981).

\section{Acknowledgements}

This paper represents preliminary results of work towards my Diplom-Thesis, supervised by Prof. Dr. A. SEILACHER. I thank him for discussion and reviewing the raanuscript. Earlier drafts have also been critisized by Prof. Dr. G. EINSELE and by Dr. A. HOFFMAN. Düring my stay in Egypt I benefited in various ways from support by Prof. Dr. H. ABBASS, Drs. EISSA, ISSAWI, HAMZA, STRougo and A.M. ZIKo. Furthermore, thanks are due to Dr. E. FUTTERER (Kiel) for carrying out the flume experiments, and to Dr. A. WETzEL for suggestions concerning porosity and bulk density determination. Technical assistance was provided by W. WETZEL (fotos), W. RIES (thin sections) and J. GHIOLD (SEM). Field work was supported by the SFB 53, which is gratefully acknowledged.

References

AIGNER, T. \& FUTTERER, E. (1978) : Kolk-Töpfe und -Rinnen (pot and gutter casts) im Muschelkalk - Anzeiger für Wattenmeer? N.Jb.Geol.Pal. Abh., jj>\$: 285-304.

ARNI, P. (1965): L'evolution des Nummulites en tant que facteur de modification des depots littoraux. - Coli, intern. Micropal., Dakar, Mem.BRGM, No.gg (1963): 7-20.

ARNI, P. \& LANTERNO, E. (1972): Considerations paleoecologiques et Interpretation des calcaires de 1'Eocene du Veronais. - Arch. Sc. Geneve, 2Js 251-283.

-.- (1976): Observations paleoecologiques dans l'Eocene du Gargano (Italie meridionale). - Arch. Sc. Geneve, 29: 287-314.

BAILEY, R.J. (1966): Scour ripples in the Ludlovian of south Radnorshire, Wales. - Sedimentology 7_: 131-136.

BLONDEAU, A. (1972): Les Nummulites. - Paris, Vuibert ed., 254 p. BOUCOT, A. (1975): Evolution and Extinction rate controls. Developm. Palaeont. Stratigr., Elsevier. 
DECROUEZ, D. \& LANTERNO, E. (1979): Les "Banks ä Nummulites" de 1 'Eocene mesogeen et leurs implications. - Arch. Sc. Geneve

3J: 67-94.

DORR, J.A. \& KAUFFMAN, E.G. (1963): Rippled Toroids from Napoleon Sandstone Member (Mississippian) of South Michigan. - J. sed. Petr., gg: $751-758$.

ENGEL, W. (1970): Die Nummuliten-Breccien im Flyschbecken von Ajdovscina in slowenien als Beispiel karbonatischer Turbidite. - Verh. geol. Bundesanst., IglQ: 570-582.

FOURNIE, D. (1975): L'analyse sequentielle et la sedimentologie de l'Ypresien de Tunisie. - Bull. Centre Rech. Pau SNPA, |:27-75. FÜRSICH, F.T. (1978): The influence of faunal condensation and mixing on the preservation of fossil benthic communities. Lethaia 11: $243-250$.

FUTTERER, E. (1977): Einregelung, Transport und Ablagerung biogener Hartteile im Strömungskanal. - Diss. Univ. Tübingen.

GOLDRING, R. (1971): Shallow-marine sedimentation. - Mem.Geol.Soc. London, 5: 1-80.

HOFFMAN, A. \& NARKIEWICZ, M. (1977): Developmental pattern of Lower to Middle Paleozoic banks and reefs. - N. Jb. Geol. Paläont. Mh. , $272-283$.

LAMING, D.J.C. (1966): Imbrication, paleocurrents and other sedimentary features in the Lower New Red Sandstone, Devonshire, England. - J. sed. Petr. J§: 940-959.

LOGAN, B.W. et al. (1969): Carbonate sediments and reefs, Yucatan Shelf, Mexico. - Am. Ass. Petr. Geol., Mem. 11: 1-198.

REINECK, H.-E. \& SINGH, I.B. (1975): Depositional Sedimentary Environments. - springer.

RONIEWICZ, P. (1969): Sedimentation of the Nummulite Eocene in the Tatra Mts. - Acta geol. polon., lg: 503-601.

SAID, R. (1962): The geology of Egypt. - Elsevier, 377 pp.

SALEM, R. (1976): Evolution of Eocene-Miocene Sedimentation patterns in parts of northern Egypt. - Am. Assoc. Petr.Geol., Bull., \$Q: $34-64$. 
SANTISTEBAN, C. \& TABERNER, C. (1980): The siliciclastic environinent as a dynamic control in the establishnient and evolution of reefs Sedimentary models. - Int.Ass.Sediment.1 st Europ.Mtg.,Abstr.: 208-211, Bochum.

SEILACHER, A. (1967): Bathymetry of trace fossils. - Mar. Geol. \$:

\section{3-428.}

SEILACHER, A. (1973) : Biostratinomy: The Sedimentology of Biologically Standarized Particles. - In: R.N. GINSBÜRG (Ed.):Evolving Concepts in Sedimentology. Johns Hopkins Univ. Press.

SEILACHER, A. (1981): Towards an evolutionary stratigraphy. - In: Concept and Method in Paleontology; Acta geol. Hispanica, lg: $39-44$.

SPECHT, R.W. \& BRENNER, R.L. (1979): Storm-wave genesis of bioclastic carbonates in Upper Jurasic epicontinental mudstones, East-central Wyoming. - J. sed. Petr. 4J: 1307-1322.

Strougo, A. (1977): Le "Biarritzien" et le Priabonien en Egypte et leurs Faunes de Bivalves. - Trav.Lab.Paleont. Univ. Paris, Fac. des Sc. d'orsay.

WANLESS, H.R. (1979): Role of physical sedimentation in carbonatebank growth. - Bull. Am. Assoc. Petr. Geol., 6_3: 547.

WILSON, I.B. (1967): Palaeoecological studies on shell-beds and associated sediments in the solway Firth. - Scott. J. Geol. 3: $329-371$. 